\title{
FUNCTIONAL DISABILITY, SAGITTAL ALIGNMENT AND PELVIC BALANCE IN LUMBAR SPONDYLOLISTHESIS
}

\author{
INCAPACIDADE FUNCIONAL, ALINHAMENTO SAGITAL E EQUILÍBRIO \\ PÉLVICO EM ESPONDILOLISTESE LOMBAR \\ DISCAPACIDAD FUNCIONAL, ALINEACIÓN SAGITAL Y BALANCE PÉLVICO \\ EN ESPONDILOLISTESIS LUMBAR
}

Luis Muñiz luna ${ }^{1}$, Hugo Vilchis Sámano ${ }^{1}$, Marcos Marban Heredia ${ }^{1}$, Enrioue Salcedo Oviedo ${ }^{1}$, Juvenal Ordaz ${ }^{1}$, Ana María Morales ${ }^{1}$,
Jorge Salvador De La Cruz Álvarez ${ }^{1}$, José Antonio Canales Nájera ${ }^{1}$, Yadira Bahena Salgado ${ }^{1}$, Edgar Negrete-Mundo ${ }^{1}$

1. Hospital de Traumatología y Ortopedia "Lomas Verdes" of the IMSS (Instituto Mexicano del Seguro Social), High Specialty Medical Unit, Spine Surgery Service, Naucalpan de Juárez, Mexico.

\begin{abstract}
Objectives: To demonstrate the recovery of lumbar sagittal pelvic alignment and sagittal pelvic balance after surgical reduction of lumbar spondylolisthesis and establish the benefits of the surgery for reduction and fixation of the lumbar spondylolisthesis with $360^{\circ}$ circumferential arthrodesis for 2 surgical approaches by clinical and functional evaluation. Method: Eight patients with lumbar spondylolisthesis treated with surgical reduction and fixation of listhesis and segmental circumferential fusion with two surgical approaches were reviewed. They were evaluated before and after treatment with Oswestry, Visual Analogue for pain and Odom scales, performing radiographic measurement of lumbar sagittal alignment and pelvic sagittal balance with the technique of pelvic radius. Results: Oswestry scales and EVA reported improvement of symptoms after treatment in 8 cases; the Odom scale had six outstanding cases reported. The lumbar sagittal alignment presented a lumbosacral lordosis angle and a lumbopelvic lordosis angle reduced in 4 cases and increased in 4 other cases; pelvic sagittal balance increased the pelvic angle in 4 cases and decreased in 3 cases and the sacral translation of the hip axis to the promontory increased in 6 cases. Conclusion: The surgical procedure evaluated proved to be useful by modifying the lumbar sagittal alignment and the pelvic balance, besides reducing the symptoms, enabling the patient to have mobility and movement and the consequent satisfaction with the surgery.
\end{abstract}

Keywords: Lumbosacral region; Spinal fusion; Arthrodesis; Bone malalignment; Postural balance.

\section{RESUMO}

Objetivos: Demonstrar a recuperação do alinhamento pélvico sagital lombar e do equilíbrio pélvico sagital após a redução e fixação cirúrgica da espondilolistese lombar e estabelecer os benefícios do procedimento cirúrgico de redução e fixação da espondilolistese lombar com artrodese circunferencial $360^{\circ}$ por dois acessos cirúrgicos por avaliação clínico-funcional. Método: Foram revisados 8 pacientes com espondilolistese lombar tratados com redução cirúrgica e fixação da listese e artrodese segmentar circunferencial por dois acessos cirúrgicos. Eles foram avaliados antes e após o tratamento pelas escalas de Oswestry, visual analógica para dor e de Odom, efetuando-se a medida radiográfica do alinhamento sagital lombar e do equilíbrio pélvico sagital com a técnica do raio pélvico. Resultados: As escalas de Oswestry e EVA relataram melhora dos sintomas após o tratamento em 8 casos, a escala de Odom teve 6 casos excelentes relatados. O alinhamento sagital lombar apresentou ângulo de lordose lombossacral e de lordose lombopélvica reduzidos em 4 casos e aumentados em 4 restantes; o equilíbrio sagital pélvico aumentou o ângulo pélvico em 4 casos e diminuiu em 3 casos e a translação sacral do eixo do quadril até o promontório aumentou em 6 casos. Conclusão: O procedimento cirúrgico avaliado comprova sua utilidade ao modificar o alinhamento sagital lombar e o equilíbrio pélvico e ao reduzir os sintomas, possibilitando que o paciente tenha mobilidade e movimento e a consequente satisfação com a cirurgia.

Descritores: Região lombar; Fusão vertebral; Artrodese; Mau alinhamento ósseo; Equilíbrio postural.

\section{RESUMEN}

Objetivos: Demostrar la recuperación de la alineación sagital lumbar y del balance pélvico sagital tras la reducción quirúrgica de la espondilolistesis lumbar y establecer los beneficios del procedimiento quirúrgico de reducción y fijación de la espondilolistesis lumbar con artrodesis circunferencial de $360^{\circ}$ por dos vías de abordaje mediante la evaluación clínico-funcional. Métodos: Se revisaron 8 pacientes con espondilolistesis lumbar tratados con reducción y fijación quirúrgica de la listesis y artrodesis circunferencial segmentaria por dos vías de abordaje. Se evaluaron antes y después del tratamiento con las escalas Oswestry, Visual Analógica del dolor y Odom, efectuando la medición radiográfica de la alineación sagital lumbar y del balance pélvico sagital con la técnica del radio pelviano. Resultados: Las escalas de Oswestry y EVA reportaron mejoría de la sintomatología después del tratamiento en los 8 casos; la escala Odom reporto 6 casos excelentes. La alineación sagital lumbar reportó los ángulos de lordosis lumbosacra y de lordosis lumbopélvica disminuidos en 4 casos y aumentados en 4 restantes; el balance pélvico sagital aumentó el ángulo pélvico en 4 casos y disminuyó en 3 casos; la traslación sacra del eje de las caderas al promontorio aumentó en 6 casos. Conclusión: El procedimiento quirúrgico evaluado demuestra su utilidad al modificar la alineación lumbar y el balance pélvico sagital y reducir la sintomatología, lo que permite la movilidad y el desplazamiento del paciente y la consecuente satisfacción con la cirugía.

Descriptores: Región lumbosacra; Fusión vertebral; Artrodesis; Desviación ósea; Balance postural.

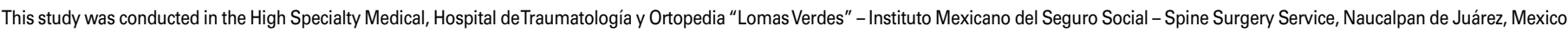
Correspondence: Av. Lomas Verdes \#2165, col. Santiago Occipaco. 53250. Naucalpan de Juárez, Estado de México, Piso 8, consultorio 816. MExico. orthos_trauma@yahoo.com.mx 


\section{INTRODUCTION}

The human spine maintains proper balance in the sagittal and coronal planes in order to minimize the muscular effort required to maintain an erect posture when standing. The minimum energy expenditure is achieved by maintaining the center of gravity of the torso right at the midpoint between the hips in the coronal plane, and immediately above the imaginary line that connects the center of the hips in the sagittal plane. ${ }^{1,2}$

Various points of reference have been described in the literature for the radiological evaluation of sagittal balance, but the reciprocal relationships between these so-called points of reference vary greatly among healthy individuals. The degree of lumbar lordosis and the sagittal rotation of the pelvis around the hip axis is one of the compensatory mechanisms that maintains balance in the sagittal plane. The compensatory rotation of the pelvis in the sagittal plane is described using the pelvic radius technique, which was described by Jackson et al. in 1994 at North Kansas City Hospital. ${ }^{2-8}$

One of the consequences of the variations in sagittal deformities (spondylolisthesis) is the reduced capacity to use this compensatory balance mechanism. 3,9,10,11

The surgical treatment, performed with arthrodesis in situ and the use of autologous bone grafts in the transverse apophysis in patients with varying degrees of slippage, together with decompression of the spinal canal, has an arthrodesis consolidation failure rate of $20 \%$. Patients with an angle of displacement due to slippage of more than $50 \%$ develop kyphotic deformity following posterior approach fusion attempts, so there have been innovations in alternative surgical procedures to resolve this problem. ${ }^{3,12}$

Today, the roles played by different fixation techniques and reduction of vertebral listhesis are not clearly specified in the literature, but reports of the esthetic benefits following surgery describe significant improvement after segmental fusions with reduction of the angle of slippage and improved alignment in the sagittal plane. At the same time, the increase in radicular lesions characteristic of instrumented reduction from the posterior approach is avoided. ${ }^{3,11,13,14}$

However, reconstruction of the anterior spine for surgical treatment of spondylolisthesis is recommended, with varying outcomes, but with lower incidence of nerve lesions. Recovery of disk height via posterior and anterior intervertebral lumbar fusion provides rigidity to the mobile segment being surgically treated. Today, intervertebral cages are used for this, and they seem to favor anterior fusion and recovery of the height of the discal space as part of the reconstruction of the anterior spine; however, there remains the question of the approach to be used for this procedure, since there are reports that additional procedures are necessary. $3,11-14$

The natural history of listhesic disease of the lumbar spine includes changes in mechanical stability that promote mechanisms of corporal compensation. Once established, they cause structural disorders of the vertebrae, the nerve roots, and adjacent soft tissue that translate clinically into lower back pain associated with disabling radicular neurological deficit with clear evidence of the loss of sagittal lumbar alignment and of sagittal pelvic balance, which is treatable using surgical reduction techniques, fixation, and circumferential arthrodesis to correct the anomalies in the lumbopelvic sagittal plane resulting in a decrease in symptoms and an improvement in the quality of life of these patients. ${ }^{11-14}$

The objective of this study is to demonstrate the recovery of sagittal lumbar alignment and sagittal pelvic balance following surgical reduction of lumbar spondylolisthesis and to define the benefits of the surgical procedures of reduction and fixation of lumbar spondylolisthesis and of $360^{\circ}$ circumferential arthrodesis from two approaches.

\section{MATERIAL AND METHODS}

This is a prospective, longitudinal, descriptive, and observational study of a case series approved by the Institutional Review Board.
We studied eight adult patients with lumbar spondylolisthesis in the Spine Surgery Service of the U.M.A.E. Hospital de Traumatología y Ortopedia "Lomas Verdes". All the patients signed an informed consent form. All patients underwent surgical treatment in two stages with an interval of from 1 to 5 weeks, the first consisting of the widening of the lumbar spinal canal in the segment narrowed by the listhesis, reduction of the listhesis, and surgical segmental fixation with the Universal Spine System (USS) transpedicle system, and bilateral posterolateral arthrodesis with an autologous bone and tricalcium phosphate graft. The second surgery consisted of anterior interbody arthrodesis with a Syncage- $L$ titanium cage and tricalcium phosphate bone substitute graft. Patients were evaluated pre and post treatment using the Oswestry Disability Index for lumbar function, ${ }^{15}$ the Visual Analog Scale for pain (VAS), ${ }^{15}$ and Odom's Criteria $^{15}$ for surgical satisfaction, performing the radiographic evaluation with the pelvic radius to determine the sagittal lumbar alignment by measuring the pelvic morphology angle (PMA), the lumbosacral lordosis angle (LSLA), and the lumbopelvic lordosis angle (LPLA) and the sagittal pelvic balance by measuring the sacral translation (ST) and the pelvic angle (PA).

\section{RESULTS}

The results of the evaluation of the sagittal lumbar alignment was measured by the PMA, the LSLA, and the LPLA, before and after surgery are shown in Table 1.

Table 1. Sagittal lumbar alignment.

\begin{tabular}{c|c|c|c|c|c|c|c|c|c|c}
\hline \multirow{2}{*}{ Patient } & \multicolumn{2}{|c|}{$\begin{array}{c}\text { Pelvic morphology } \\
\text { angle (PMA) }\end{array}$} & \multicolumn{2}{|c|}{$\begin{array}{c}\text { Lumbosacral lordosis } \\
\text { angle (LSLA) }\end{array}$} & \multicolumn{3}{|c}{$\begin{array}{c}\text { Lumbopelvic lordosis } \\
\text { angle (LPLA) }\end{array}$} \\
\cline { 2 - 10 } & Pre & Post & \multicolumn{2}{|c|}{ Pre } & \multicolumn{2}{c|}{ Post } & \multicolumn{2}{c|}{ Pre } & \multicolumn{2}{c|}{ Post } \\
\cline { 2 - 10 } & & & T12 & L1 & T12 & L1 & T12 & L1 & T12 & L1 \\
\hline Case 1 & $25^{\circ}$ & $25^{\circ}$ & $57^{\circ}$ & $56^{\circ}$ & $48^{\circ}$ & $45^{\circ}$ & $82^{\circ}$ & $81^{\circ}$ & $73^{\circ}$ & $70^{\circ}$ \\
\hline Case 2 & $24^{\circ}$ & $24^{\circ}$ & $44^{\circ}$ & $42^{\circ}$ & $52^{\circ}$ & $50^{\circ}$ & $68^{\circ}$ & $66^{\circ}$ & $76^{\circ}$ & $74^{\circ}$ \\
\hline Case 3 & $25^{\circ}$ & $25^{\circ}$ & $42^{\circ}$ & $40^{\circ}$ & $46^{\circ}$ & $44^{\circ}$ & $67^{\circ}$ & $65^{\circ}$ & $71^{\circ}$ & $69^{\circ}$ \\
\hline Case 4 & $24^{\circ}$ & $24^{\circ}$ & $56^{\circ}$ & $54^{\circ}$ & $61^{\circ}$ & $59^{\circ}$ & $80^{\circ}$ & $78^{\circ}$ & $85^{\circ}$ & $83^{\circ}$ \\
\hline Case 5 & $12^{\circ}$ & $12^{\circ}$ & $68^{\circ}$ & $66^{\circ}$ & $57^{\circ}$ & $54^{\circ}$ & $80^{\circ}$ & $78^{\circ}$ & $69^{\circ}$ & $66^{\circ}$ \\
\hline Case 6 & $38^{\circ}$ & $38^{\circ}$ & $52^{\circ}$ & $51^{\circ}$ & $57^{\circ}$ & $56^{\circ}$ & $90^{\circ}$ & $89^{\circ}$ & $95^{\circ}$ & $94^{\circ}$ \\
\hline Case 7 & $24^{\circ}$ & $24^{\circ}$ & $72^{\circ}$ & $69^{\circ}$ & $54^{\circ}$ & $53^{\circ}$ & $96^{\circ}$ & $93^{\circ}$ & $78^{\circ}$ & $77^{\circ}$ \\
\hline Case 8 & $24^{\circ}$ & $24^{\circ}$ & $65^{\circ}$ & $63^{\circ}$ & $62^{\circ}$ & $60^{\circ}$ & $89^{\circ}$ & $87^{\circ}$ & $86^{\circ}$ & $84^{\circ}$ \\
\hline
\end{tabular}

We observed that the pelvic morphology angle showed no difference between the pre-and postoperative measurements and that the lumbosacral and lumbopelvic lordosis decreased in four cases and increased in 4 cases following the procedure.

Pelvic sagittal balance was measured by the PA, the VP, and the VAPSS1. The results are shown in Table 2 in degrees or millimeters.

Table 2. Sagittal pelvic balance.

\begin{tabular}{c|c|c|c|c|c|c}
\hline \multirow{2}{*}{ Patient } & \multicolumn{2}{|c|}{$\begin{array}{c}\text { Pelvic angle } \\
\text { (PA) }\end{array}$} & $\begin{array}{c}\text { Sacral promontory } \\
\text { translation (VP) }\end{array}$ & $\begin{array}{c}\text { Posterosuperior sacral translation } \\
\text { angle of S1 (VAPSS1) }\end{array}$ \\
\cline { 2 - 7 } & Pre & Post & Pre & Post & Pre & Post \\
\hline Case 1 & $14^{\circ}$ & $19^{\circ}$ & $7 \mathrm{~mm}$ & $15 \mathrm{~mm}$ & $30 \mathrm{~mm}$ & $41 \mathrm{~mm}$ \\
\hline Case 2 & $34^{\circ}$ & $26^{\circ}$ & $48 \mathrm{~mm}$ & $74 \mathrm{~mm}$ & $30 \mathrm{~mm}$ & $64 \mathrm{~mm}$ \\
\hline Case 3 & $22^{\circ}$ & $25^{\circ}$ & $31 \mathrm{~mm}$ & $27 \mathrm{~mm}$ & $57 \mathrm{~mm}$ & $62 \mathrm{~mm}$ \\
\hline Case 4 & $27^{\circ}$ & $28^{\circ}$ & $26 \mathrm{~mm}$ & $28 \mathrm{~mm}$ & $60 \mathrm{~mm}$ & $61 \mathrm{~mm}$ \\
\hline Case 5 & $46^{\circ}$ & $24^{\circ}$ & $75 \mathrm{~mm}$ & $41 \mathrm{~mm}$ & $103 \mathrm{~mm}$ & $58 \mathrm{~mm}$ \\
\hline Case 6 & $19^{\circ}$ & $20^{\circ}$ & $10 \mathrm{~mm}$ & $15 \mathrm{~mm}$ & $46 \mathrm{~mm}$ & $52 \mathrm{~mm}$ \\
\hline Case 7 & $22^{\circ}$ & $22^{\circ}$ & $10 \mathrm{~mm}$ & $27 \mathrm{~mm}$ & $38 \mathrm{~mm}$ & $58 \mathrm{~mm}$ \\
\hline Case 8 & $23^{\circ}$ & $21^{\circ}$ & $18 \mathrm{~mm}$ & $26 \mathrm{~mm}$ & $41 \mathrm{~mm}$ & $57 \mathrm{~mm}$ \\
\hline
\end{tabular}

We observed an increase in the pelvic angle in four cases, a decrease in three cases, and one case that remained consistent from pre- to postoperative measurements. The sacral translation of the axis from the hips to the promontory increased in six cases and decreased in two, while the sacral translation from the axis of the 
hips to the posterosuperior angle of S1 increased in seven cases and decreased in one.

The results of the Oswestry Disability Index for lumbar function and the VAS were obtained both pre- and postoperatively and Odom's Criteria for postoperative satisfaction with the surgery are described in Table 3.

Table 3. Evaluation scales.

\begin{tabular}{c|c|c|c|c|c|c|c|c|c}
\hline \multirow{2}{*}{ Patient } & \multicolumn{4}{|c|}{ Oswestry } & \multicolumn{4}{c|}{ VAS } & Odom \\
\cline { 2 - 10 } & \multicolumn{2}{|c|}{ Pre } & \multicolumn{2}{c|}{ Post } & \multicolumn{2}{c|}{ Pre } & \multicolumn{2}{c|}{ Post } & \\
\hline Case 1 & 35 & $70 \%$ & 5 & $10 \%$ & 8 & $80 \%$ & 0 & $0 \%$ & Excellent \\
\hline Case 2 & 48 & $96 \%$ & 4 & $8 \%$ & 10 & $100 \%$ & 0 & $0 \%$ & Excellent \\
\hline Case 3 & 29 & $58 \%$ & 4 & $8 \%$ & 9 & $90 \%$ & 0 & $0 \%$ & Excellent \\
\hline Case 4 & 45 & $90 \%$ & 5 & $10 \%$ & 10 & $100 \%$ & 0 & $0 \%$ & Good \\
\hline Case 5 & 38 & $76 \%$ & 3 & $6 \%$ & 9 & $90 \%$ & 0 & $0 \%$ & Excellent \\
\hline Case 6 & 38 & $76 \%$ & 4 & $8 \%$ & 9 & $90 \%$ & 1 & $10 \%$ & Excellent \\
\hline Case 7 & 45 & $90 \%$ & 11 & $22 \%$ & 10 & $100 \%$ & 2 & $20 \%$ & Good \\
\hline Case 8 & 37 & $74 \%$ & 3 & $6 \%$ & 9 & $90 \%$ & 0 & $0 \%$ & Excellent \\
\hline
\end{tabular}

Table 3 shows a considerable decrease in the Oswestry and VAS scores following the procedure in eight cases, and Odom's Criteria reports six excellent and two good ratings.

\section{DISCUSSION}

The pelvic morphology angle remained consistent in the preand postoperative measurements, as reported by Jackson and colleague $^{4-7}$ and Legate and colleagues. ${ }^{9,10}$

The parameters of lumbosacral and lumbopelvic lordosis changed in $100 \%$ of the cases following the procedure, $50 \%$ increasing and the other $50 \%$ decreasing their values, but it was not possible the establish any relationship with the change in the pelvic balance parameter described by Legaye, ${ }^{10}$ Tebet, ${ }^{11}$ Lazennec, ${ }^{13}$ and Videbaek. ${ }^{14}$

We observed modifications in the sagittal lumbar alignment and the sagittal pelvic balance following the surgical procedure of reduction and posterior fixation of the listhesis and the reconstruction of the anterior spine with a titanium cage, although we observed no correlation between them, as reported by Videbaek and colleagues. ${ }^{14}$
While we cannot say that there is recovery of the alignment and balance, we can say that the technique of reduction and fixation with circumferential arthrodesis alters the balance of the lumbar and pelvic segment.

Changes in the sacrolumbar and sacropelvic indices and their variability are described as the consequences of the modification to pelvic balance, also referenced by Roussouly and colleagues. ${ }^{8}$

The Oswestry Disability Index for lumbar function showed an evident improvement in the disabling painful lumbar symptoms ranging from 50 to $88 \%$, which is closely related to that obtained in the VAS, with improvement in pain ranging from 80 to $100 \%$. It is possible that this reflects the influence of not only the reconstruction of the anterior column as stated by Roussouly and colleagues, ${ }^{8}$ but also of the decompression of the lumbar stenosis.

Odom's Criteria validated the use of the surgical procedure with $80 \%$ of the outcomes rated excellent and $20 \%$ rated good.

\section{CONCLUSION}

Circumferential arthrodesis in patients with lumbar spondylolisthesis is a resource that demonstrates its usefulness by modifying lumbar alignment and decreasing the lumbosacral lordosis angle. It also changes sagittal pelvic balance, which consequently reduces painful symptoms, since modifying the pathological balance of the lumbar spine reduces pain by reducing the distension of ligamentous structures and the overload on articular structures, resulting in improvements in the quality of life of the patients objectively, both in work and personal activities, and with a high level of patient satisfaction since it restores the lumbar spine to a state that allows patient mobility and displacement, showing an improvement in the quality of life of the patient.

This study demonstrates that circumferential arthrodesis in patients with lumbar pain secondary to spondylolisthesis alters the balance of the lumbar and pelvic segment, a consequence of the modification of the degrees of sacrolumbar and sacropelvic lordosis and improves the disabling lumbar pain, with good and excellent outcomes in most patients.

All authors declare no potential conflict of interest concerning this article.

\section{REFERENCES}

1. Miralles RC: Biomecánica de la columna. Rev Soc Esp Dolor. 2001;8:(Supl II):2-8.

2. Yaszemski MJ, White AA III, Panjabi MM. Biomecánica de la columna. In: Fardon DF Garfio SR, ed. Oku actualizaciones en cirugía ortopédica y traumatología. Columna 2. 2a ed. Barcelona: Medicina STM Editores, SL; 2003.p.17-25.

3. Connolly PJ Fredrickson BE. Tratamiento quirúrgico de la espondilolistesis y la espondilósis ístmica y displásica. In: Fardon DF, Garfio SR, ed. Oku actualizaciones en cirugía ortopédica y traumatología. Columna 2. 2a. ed. Barcelona: Medicina STM Editores, SL; 2003. p.387-94.

4. Jackson RP, Kanemura T, Kawakami N, Hales C. Lumbopelvic lordosis and pelvic balance on repeated standing lateral radiographs of adult volunteers and untreated patients with constant low back pain. Spine (Phila Pa 1976). 2000; 25(5):575-86.

5. Jackson RP, Hales $\mathrm{C}$. Congruent spinopelvic alignment on standing lateral radiographs of adult volunteers. Spine (Phila Pa 1976). 2000; 25(21):2808-15

6. Jackson RP, McManus AC. Radiographic analysis of sagittal plane alignment and balance in standing volunteers and patients with low back pain matched for age, sex, and size. A prospective controlled clinical study. Spine (Phila Pa 1976). 1994:19(14):1611-8.

7. Jackson RP, Peterson MD, McManus AC, Hales C. Compensatory spinopelvic balance over the hip axis and better reliability in measuring lordosis to the pelvic radius on standing lateral radiographs of adult volunteers and patients. Spine (Phila Pa 1976). 1998; 23(16):1750-67.

8. Roussouly P, Gollogly S, Berthonnaud E, Dimnet J. Classification of the normal variation in the sagittal alignment of the human lumbar spine and pelvis in the standing position. Spine (Phila Pa 1976). 2005; 30(3):346-53

9. Legaye J, Duval-Beaupère G. Sagittal plane alignment of the spine and gravity: a radiological and clinical evaluation. Acta Orthop Belg. 200; 71(2):213-20.

10. Legaye J, Duval-Beaupère G. Hecquet J, Marty C. Pelvic incidence: a fundamental pelvic parameter for three-dimensional regulation of spinal sagittal curves. Eur Spine J. 1998; 7(2):99-103.

11. Tebet MA. Conceitos atuais sobre equilíbrio sagital e classificacão da espondilólise e espondilolistese. Rev Bras Ortop. 2014:49(1):3-12.

12. Jost $B$, Cripton PA, Lund T, Oxland TR, Lippuner $K$, Jaeger $P$, et al. Compressive strength of interbody cages in the lumbar spine: the effect of cage shape, posterior instrumentation and bone density. Eur Spine J. 1998: 7(2):132-41.

13. Lazennec JY, Ramaré S, Arafati N, Laudet CG, Gorin M, Roger B, et al. Sagittal alignment in lumbosacral fusion: relations between radiological parameters and pain. Eur Spine J. 2000: 9(1):47-55.

14. Videbaek TS, Bünger CE, Henriksen M, Neils E, Christensen FB. Sagittal spinal balance after lumbar spinal fusion: the impact of anterior column support results from a randomized clinical trial with an eight- to thirteen-year radiographic follow-up. Spine (Phila Pa 1976). 201: 36(3):183-91.

15. Thomas AMC. La columna vertebral. In: Pynset P, Fairbank J, Carr A, editores. Medición de los resultados en ortopedia. Edición española. Barcelona: Masson AS:1996. p.109-62. 